\title{
Higher Education for Sustainability in the Developing World: A Case Study of Rafik Hariri University ${ }^{1}$ in Lebanon
}

\author{
Jamil Hammoud ${ }^{13}$ and Mohamed Tarabay ${ }^{23}$
}

\begin{abstract}
Responding to heightened global interest in and concern for the sustainability of the planet and our ways of life on it, The United Nations' Transforming Our World: The 2030 Agenda for Sustainable Development (2015) came out as a very ambitious and historic global agreement. The agenda identified what have become known as the 17 Sustainable Development Goals (SDGs), along with their detailed targets to mobilize and guide global efforts toward ending poverty, fostering peace, safeguarding human rights and protecting the planet.

Education for Sustainable Development forms part of Target 4.7 of Sustainable Development Goal 4, which seeks to "ensure that all learners acquire the knowledge and skills needed to promote sustainable development, including, among others, through education for sustainable development and sustainable lifestyles..."

Departing from the Brundtland Commission's (1987) definition of sustainable development as a paradigm of resource use that "meets the needs of the present without compromising the ability of future generations to meet their own needs," universities have progressively been incorporating sustainability values, practices and initiatives into their activities, throughout the realm of what they do in teaching, research, administration and operational systems. Indeed, Commitment to sustainability at universities worldwide dates back to the 1980's, with a number of landmarks and declarations such as the Magna Charta of European Universities (1988), and the Talloires Declaration of University Presidents for a Sustainable Future (1990).

However, the debate so far has centered mostly on the rationale and reasoning for broad adoption, rather than the various actions to be undertaken by higher education institutions (HEIs). Moreover, Efforts and initiatives to integrate sustainability into higher education in the developing world have been ad-hoc, modest and small (Mohamedbhai 2012). We could only find a few research studies covering such efforts and initiatives anyways (Awuzie \& Emuze, 2017; Bhat et al., 2017; KhalafKairouz, 2012).

This paper aims to describe sustainable practices of higher education institutions in the developing world, via a case study of Rafik Hariri University in Lebanon. The authors utilize the 12 Features of Sustainable Society, developed by the Forum for the Future (2003) as an analytical framework, based on the Five Capitals Model. The research instrument was a questionnaire derived from the 12 Features of a Sustainable Society and designed to identify the strategies, policies, values and practices pursued by the university to contribute to sustainable development.

The outcome is a detailed level analysis into the ways in which a small institution of higher education in a developing country contributes to the betterment of the world via engagement in sustainability.
\end{abstract}

Keywords Sustainability; Sustainable Development; Higher Education; Developing World; Higher Education for Sustainable Development; Rafik Hariri University; Lebanon; ESD; SDG; HESD

${ }^{1}$ The authors express their gratitude to RHU President Ahmad Smaili, and Sustainable Campus Initiative Committee Chair Mahmoud Halablab for their valuable contributions in data and information collection. ${ }^{2} \mathrm{H}$ Associate Professor, Rafik Hariri Universit.

${ }^{3}$ Assistant Professor, Rafik Hariri University. 


\section{Background}

Events and developments over the past couple of decades, in our increasingly globalized world and in the international economy converge, one way or another, to heighten concern about the sustainability of our present ways of living, interacting with each other and dealing with our planet.

Indeed, phenomena like global warming, desertification and resources depletion had remained in our minds as abstract notions of hard to imagine bad things which will not happen anytime within the near future. Yet rapid advancements in technologies over recent years have made it possible for us to identify and accumulate evidence, that the threats are real and unfolding right before our eyes. Mountains of ice for instance, are actually melting in the North Pole. Moreover, unexpected and unpredictable weather patterns have become mainstream news in various parts of the world.

Knowing what we know and as much as we know today, can we continue to burn as much fossil fuel as we have before, in spite of the damage that causes to the ozone layer? Is it possible to continue emitting as much greenhouse gases as we do, regardless of the measurable increase in the average temperature of the earth? Is it socially responsible to engage in a number of economic activities characterized by high social cost and externalities? It is these questions and similar ones that have made sustainability occupy center stage in our present daily lives all over the world.

Stepping up and forward to face the challenge, The United Nations' Transforming Our World: The 2030 Agenda for Sustainable Development (2015) came out as a very ambitious and historic global agreement. The agenda identified what have become known as the 17 Sustainable Development Goals (SDGs), along with their detailed targets to mobilize and guide global efforts toward ending poverty, fostering peace, safeguarding human rights and protecting the planet.

Of particular interest to us in the SDG's and their detailed targets is Education for Sustainable Development, which forms part of Target 4.7 of Sustainable Development Goal 4, which seeks to "ensure that all learners acquire the knowledge and skills needed to promote sustainable development, including, among others, through education for sustainable development and sustainable lifestyles..."

Going backward a bit to clarify matters, according to the Forum for the Future (200607), The term "sustainable development" gained prominence following the Rio Earth Summit in 1992, which improved upon the initial framework introduced at the United Nations Conference on the Human Environment, Stockholm in 1972. Up until this juncture, development implied economic progress, while sustainability denoted environmental concerns and issues, and the two were taken in separation from each other. The Rio Earth Summit (United Nations, 1992) made it clear in its declaration that "... we can no longer think of environment and economic and social development as isolated fields." Yet for scholars, the notion of sustainable development still meant different things, depending on the angle from which one is looking.

Departing from the Brundtland Commission's (1987) definition of sustainable development as a paradigm of resource use that "meets the needs of the present without compromising the ability of future generations to meet their own needs," universities worldwide have progressively been incorporating sustainability values, practices and 
initiatives into their activities, throughout the realm of what they do in teaching, research, administration and operational systems. Indeed, Commitment to sustainability at universities in general dates back to the 1980's, with a number of landmarks and declarations such as the Magna Charta of European Universities (1988), and the Talloires Declaration of University Presidents for a Sustainable Future (1990).

However, the debate so far has centered mostly on the rationale and reasoning for broad adoption, rather than the various actions to be undertaken by higher education institutions (HEIs). Moreover, Efforts and initiatives to integrate sustainability into higher education in the developing world have been ad-hoc, modest and small (Mohamedbhai 2012).

\section{Research Issue, Design and Methodology}

The need for this study is in fact threefold. First, if HEI's in general are to make a tangible positive contribution toward the attainment of SDG's, the higher education for sustainable development debate must shift from its present focus on the rationale and reasoning for broad adoption, to alternative actions, strategies and initiatives, which could possibly be undertaken by HEI's, given their core competencies, capacities and constraints. Indeed, innovative ideas, experimentation and best practices would eventually converge toward elaboration of pragmatic guiding principles and orientations. Second, it is ironic that the developing world needs more than anything else, and stands to potentially benefit the most from, sustainable development. Yet, studies of higher education for sustainable development in the developing world are not many. In fact, we could only find a few studies covered later on in this paper. It is entirely possible that sustainability efforts and initiatives are there, but the gap is in the research that covers them. If this were the case, then we are not learning from what we are doing. Moreover, we will not know until we direct efforts toward filling the gap in the research.

Third, analysis and description of Rafik Hariri University's approach to sustainability would allow the stakeholders in this small and ambitious institution to reflect upon what they are doing, and how they are doing it, in hopes of moving forward toward the university's main aim of fulfilling its mission, while leading in providing practical models for sustainable practices and lifestyles to its community and society.

With these three needs in mind, the research issue of this paper is to describe and analyze the sustainability efforts undertaken by Rafik Hariri University in Lebanon over the past three years or so, as a sample more or less reflective of the state of higher education for sustainable development in the developing world.

The authors utilized the 12 Features of Sustainable Society (Appendix A), developed by the Forum for the Future (2003) as an analytical framework, and based on the Five Capitals Model. The research instrument was a structured interview questionnaire (Appendix B) derived from the 12 Features of a Sustainable Society and designed to identify the strategies, policies, values and practices pursued by the university to contribute to sustainable development. It is worthwhile noting here that the same study was done by Dr. Andy Johnson (Forum for the Future, 2006-07) and it included 15 European, Canadian, Japanese, Mexican, and Australian HEI's. Consequently, we will be able to benefit from a comparison of our targeted case study with these institutions. 
The outcome is a detailed level analysis into the ways in which a small institution of higher education in a developing country contributes to the betterment of the world via engagement in sustainability.

\section{Literature Review}

\section{1 -A. Sustainability: The Global Agenda}

International Earth Summits have been decennial conferences of nations and world leaders, held since 1972 by the United Nations. Their purpose is to address global challenges of development, which are deemed too great for nations to face them alone, via cooperation and collaboration of major world stakeholders. Five summits have been held thus far in Stockholm, Nairobi, Rio de Janeiro, Johannesburg and Rio de Janeiro again successively.

The first Earth Summit of Stockholm (United Nations, 1972a) was the first global institutional forum to recognize and agree on the urgent need to respond to the problem of environmental deterioration, and witnessed the emergence of international environmental law. The Declaration on the Human Environment or the Stockholm Declaration (United Nations, 1972b) spelled out the guiding principles for various global environmental issues, including human rights, natural resources management, and pollution prevention.

Yet sustainable development, as we know it and understand it today, was popularized and defined as a concept by the Brundtland Commission (United Nations, 1987), established by the United Nations in 1983, in an initiative to bring nations of the world together to face environmental challenges. In its infamous report entitled "Our Common Future", the commission defined sustainable development as a paradigm of resource use that "meets the needs of the present without compromising the ability of future generations to meet their own needs."

It wasn't until the Earth Summit of Rio in 1992 (Meakin, 1992) that United Nations members and world stakeholders linked the environment and development, by declaring that protection of the environment and social and economic development are fundamental to sustainable development.

The Summit was a major UN conference held in response to UN member States' tendency to cooperate and work together globally on sustainability and development issues in the aftermath of the Cold War. The Summit resulted into the adoption of the Rio Declaration on Environment and Development (United Nations, 1992a), Agenda 21 (United Nations, 1992b) and the Forest Principles (United Nations, 1992c). In 2013, the UN Commission on Sustainable Development was established to follow up on compliance with the agreements made in the Summit. The Commission was later on replaced by the High Level Political Forum on Sustainable Development.

The fourth Earth Summit of Johannesburg (United Nations, 2002a), also known as Rio +10 , reaffirmed commitment to the declarations and agreements made 10 years earlier in Rio. The conference resulted mainly into the Johannesburg Declaration on Sustainable Development (United Nations, 2002b), which builds on earlier commitments made in the earth summits of 1972 and 1992. Although the declaration was a statement 
of general terms, it focused on multilateralism as the way forward for facing "the worldwide conditions that pose severe threats to the sustainable development of our people, which include: chronic hunger; malnutrition; foreign occupation; armed conflict; illicit drug problems; organized crime; corruption; natural disasters; illicit arms trafficking; trafficking in persons; terrorism; intolerance and incitement to racial, ethnic, religious and other hatreds; xenophobia; and endemic, communicable and chronic diseases, in particular HIV/AIDS, malaria and tuberculosis."

Convening again in Rio, the United Nations held the $5^{\text {th }}$ Earth Summit, also known as Rio +20

(Pisano, Andreas and Berger, 2012), in 2012. Aside from adopting guidelines on green economy policies, establishing an intergovernmental process under the General Assembly to prepare options on a strategy for sustainable development financing, and adopting a political outcome document entitled "the Future We Want", the summit's main achievement was to launch a process to develop a set of Sustainable Development Goals (SDGs), which will build upon the Millennium Development Goals (MDG's) that ended in 2015.

Formally named "Transforming our World: the 2030 Agenda for Sustainable Development", and shortened to "2030 Agenda", the United Nations General Assembly adopted Resolution A/RES/70/1 in 2015, which specified 17 SDG's (Appendix C), along with their corresponding 169 targets, covering social and economic development issues including poverty, hunger, health, education, climate change, gender equality, water, sanitation, energy, urbanization, environment and social justice (United Nations, 2015). In particular, Education for Sustainable Development forms part of Target 4.7 of Sustainable Development Goal 4, which seeks to "ensure that all learners acquire the knowledge and skills needed to promote sustainable development, including, among others, through education for sustainable development and sustainable lifestyles..."

Apart from the successive earth summits, in 2002, the United Nations declared 2005-14 as the Decade of Education for Sustainable Development (DESD), with the objective of integrating the principles and practices of sustainable development into all aspects of education and learning, and appointed UNESCO as the lead implementing agency (UNESCO, 2014). DESD meant also to promote the "behavioral changes that are necessary if environmental integrity and economic viability are to be preserved." Aside from reported progress made on a number of fronts, DESD witnessed the creation of networks of HEIs in many world regions (MESA in Africa, ProsPER.Net in AsiaPacific, COPERNICUS Alliance in Europe, ARIUSA in Latin America and the Caribbean) to promote and advance building capacity, sharing experiences and expanding the influence of education for sustainable development. The decade's final report notes that "There is now an increased recognition at the international policy level that education is essential to the advancement of sustainable development, with many countries committed to continuing to work to advance ESD at the national and local levels".

With UNESCO being the main organizational arm of the United Nations to address and deal with issues of education, UNESCO held the World Conference on Education for Sustainable Development (UNESCO 2015) in Aichi-Nagoya, Japan, in 2014, to mark the end of the United Nations (UN) Decade of Education for Sustainable Development 
(DESD, 2005-2014), and to launch UNESCO's Global Action Program (UNESCO, 2017). As a follow up to DESID, which envisioned a world "where everybody has the opportunity to benefit from education and learn the values, behavior and lifestyles required for a sustainable future and for positive societal transformation", UNESCO's GAP identified five Priority Action Areas: 1) Advancing policy; 2) Transforming learning and training environments; 3) Building capacities of educators and trainers; 4) Empowering and mobilizing youth; and 5) Accelerating sustainable solutions at local level.

\subsection{Sustainability the Higher Education Agenda.}

As far as HEI's and universities are concerned, there have been a number of important landmarks in the evolution of developing initiatives and approaches to integrate sustainable development issues and aspects into university policies, programs, research, extension and operational management.

In 1988, rectors and heads of 388 universities adopted the Magna Charta of European Universities (Magna Charta Universitatum, 1988). In one of its principles, the Magna Charta stated, "that universities must give future generations education and training that will teach them, and through them others, to respect the great harmonies of their natural environment and of life itself."

In 1990, university leaders gathered to sign the Talloires Declaration (ULSF, 1990) which defined the role of the sustainable university and set out key actions on campuses to promote sustainable development, via commitment to a ten-point action plan for incorporating sustainability and environmental literacy in teaching, research, operations and outreach. Over 500 university leaders from 50 countries signed the declaration.

In 1993, the International Association of Universities, or IAU, adopted the Koyto Declaration on Sustainable Development (IAU, 1993), as a comprehensive policy statement which outlines all the main issues related to the role of universities in advancing sustainable development. In its opening clause, the declaration urges universities to seek, establish and disseminate a clearer understanding of sustainable development. Since the adoption of the declaration, the IAU has continued to focus on sustainable development as a key action area, and published an online portal on Higher Education for Sustainable Development (http://www.iau-hesd.net/).

In 1994, hundreds of European universities responded to the Rio Earth Summit by signing the COPERNICUS University Charter for Sustainable Development (COPERNICUS, 1994). The network of signatories expanded over time to include more 320 universities from over 38 countries. The Charter marked an important step toward raising consciousness within the European universities about the need to cooperate to preserve the future. In agreeing to the Charter, universities basically declared that they will give sustainable development an important place in their priorities. This meant that a responsible balance between economic, ecological and socio-cultural aspects will have to be reached in curricula, institutional management and services.

In 2001, the International COPERNICUS Conference "Higher Education for Sustainability-Towards the World Summit on Sustainable Development (Rio+10)" was held at the University of Lüneburg, Germany, and resulted into the Declaration on Higher Education for Sustainable Development (COPERNICUS, 2001). In the 
Declaration, the signatories call upon HEI's, NGO's, governments, the United Nations and UNESCO to commit to specific actions, based on recognition that, "The ultimate goal of education for sustainable development is to impart the knowledge, values, attitudes and skills needs to empower people to bring about the changes required to achieve sustainability."

More recently, and building upon the successes of the Mainstreaming Environment and Sustainability in African Universities (MESA), the nascent Mainstreaming Environment and Sustainability in the Caribbean Universities (MESCA) and the Asia-Pacific Regional University Consortium (RUC), the United Nations Environment Programme (UNEP) established the Global Universities Partnership on Environment for Sustainability (GUPES), as a network of 530 universities across the globe to integrate environment and sustainability practices into the curricula (UNEP, 2012).

Also in 2012, The Higher Education Sustainability Initiative (HESI) for Rio+20 was launched by a group of UN partners, as an unprompted initiative for higher education institutions in the run-up to the Rio+20 Conference (United Nations, 2012). HESI included the signature of a common declaration for sustainable development, a presentation of the institution's plan for sustainability for 2012-2015 and the voluntary submission of commitments to the Rio +20 registry. The Initiative was dubbed a success, as it resulted into commitments on behalf of 272 organizations from 47 countries, representing $36 \%$ of all commitments made in the Rio +20 Conference.

A preliminary study was conducted to review the progress of the 272 commitments made by HEIs, and better understand the role of the Rio +20 commitments in facilitating this progress (Simon and Haertle, 2014). The study concluded that a promising $73 \%$ of all pledging institutions were found to have made at least partial progress on their commitments, either directly or indirectly.

\subsection{Integrating Sustainable Development into Higher Education}

\subsubsection{In General}

Aside from being a high priority issue on the global agenda and the higher education agenda, as shown above, the role of higher education in the promotion of sustainability and sustainable development has also been a research priority, from various aspects, perspectives and dimensions.

Yet the Rio Earth Summit of 1992 marked a defining turn of attention, around the notion of education for sustainable development (ESD), which inspired a wave of studies, research projects, reports, case studies, as well as media coverage and journalistic reporting (Wals, 2009; Wright \& Pullen, 2007).

Examination of research and studies by a number of authors suggests the emergence of two areas of interest: theory and case studies (Barth \& Rieckmann, 2016; Karatzoglou, 2012; Corcoran, Walker, and Wals 2004; Fien, 2002). Karatzoglou criticized the lack of using rigorous conceptual frameworks in theoretical papers, and the focus on the descriptive nature of case studies. Moreover, the role of higher education in sustainable development continues to be vague and debatable (Fonseca, Macdonald, Dandy, \& Valenti, 2011). According to Leal Filho (2011 and 2000), a small number of universities have been successful in integrating sustainable development in their programs, due to a 
number of misconceptions, among which are the following: sustainability is too abstract, sustainability is too broad, no personnel to look after it, resources needed do not justify it, and the theme has no scientific basis.

With these orientations in mind, Wright and Pullen (2007) observed that studies of education for sustainability, ecological physical operations, university policy, and case studies dominate published papers. In particular, Tapia-Fonllem et al. (2017) states that curriculum design that includes sustainability issues constitutes one of the preferred practices of universities (Barth \& Rieckmann, 2012; Cusick, 2008; Desha, Hargroves, \& Smith, 2009; Doniec, 2006; Kagawa, 2007; Lozano, Lukman, Lozano, Huisingh, \& Lambrechts, 2011; McMillin \& Dyball, 2009).

To that end, Leal Filho (2011) suggests that the implementation of sustainable development in HEI's is not only a matter of policy, blueprints or strategies. He goes on to propose that, "declarations or action plans are useless, unless they can be backed up by concrete action in one or more of the following areas: (a) curriculum greening; (b) campus operations; (c) research; (d) extension (i.e. continuing education and further education programs); (e) concrete projects.

Continuing along the same lines of discussion, Shepard (2016) indicated that disarticulated efforts are dedicated to environmental-physical aspects and eco-efficiency, while others consider the inclusion of sustainability topics into the curriculum and in research projects. Meanwhile, social aspects of sustainability (equity, cooperation, justice, etc.) are practically neglected or ignored in those efforts, and the integration of research, teaching, and practice of pro-sustainability aspects is just not there yet. In light of these realities, a number of authors propose to define and benchmark key performance indicators of sustainable development in the higher education context, identify assessment and intervention tools, and determine links among sustainability teaching, research, and practice to focus the effectiveness of higher education, and clarify its contributions to sustainability (Clugston \& Calder, 1999; Fonseca et al., 2011; Shriberg, 2004).

Aside from the direct role of higher education in sustainable development, UNESCO (2018) provides extensive coverage of issues and trends relating to education for Sustainable development. It focuses attention on understanding education for sustainable development and explores how ESD is being implemented in the five priority action areas of GAP. Also from UNESCO, Owens (2017), evaluated the inclusion of higher education into the development agenda in general and the introduction of the SDGs into "the parallel but fragmented multilateral and university agendas." She concluded that if higher education is to play an important role in the sustainable development framework, publicly-funded research and regional higher education partnerships will be essential factors.

Leal Filho (2011) reviewed the status of sustainable development at universities and presented issues which need to be considered in ensuring sustainable development is integrated in higher education institutions in a systematic way. He identified four challenges as follows: the need for broader interpretation of sustainability, the need to translate sustainability to different audiences and to different nations, the need to operationalize sustainability, and the need to raise more support for sustainability. Forum for the Future (2006-07), reported on research done by Dr. Andy Johnston, who 
undertook a research project aiming to disentangle the performance of higher education institutions in sustainable development by surveying the practices of fifteen European, Canadian, Australian, Japanese, American and Mexican institutions. The report presented a set of case studies to show how organizations are approaching sustainable development through natural resource reduction, innovative teaching practices and curriculums, research and consultancy, building maintenance, alternative transport and financial management.

\subsubsection{In the Developing World}

Research coverage of higher education for sustainable development in the developing world is still lacking in many regards. We could only find a small number of studies conducted mostly as individual case studies. Given the particularities of case studies, we could not possibly identify emerging themes or trends or issues. Consequently, we summarize below what we found in chronological order.

(Bhat et al., 2017) explored the relationship between environmental education and sustainable development in India. Their exploration described various projects, academic programs and currcular development initiatives in India, intended to implement sustainable development in education.

Awuzie and Emuze (2017) highlighted the drivers for sustainable development implementation, in South African universities, focusing on a case study of the Central University of Technology. Although, the study identifies a host of drivers, cost reduction and cost savings were found to be the overriding driver.

Tapia-Fonllem et al. (2017) analyzed the influence that four higher education institutions in Sonora, Mexico, have on students' Pro-Sustainability Orientation (PSO). They that a coherent PSO factor emerges from the interrelations among pro-environmental dispositional and behavioral variables reported by students. However, university programs and actions did not result into statistically significant differences between freshmen and senior students.

Kieu, Singer, and Gannon (2016) Investigated challenges in education for sustainable development (ESD) implementation in teacher education institutions (TEIs) in Vietnam. They found a significant gap between ESD cognition and ESD teaching capacity among teacher trainees and they referred that to the prevalence of top-down pedagogy

Referring to the introduction of a major in environmental science, at Notre Dame University, Khalaf-Kairouz (2012) presented the program's components, goals and implementation. The Author pointed out that the program was successful in offering general education requirements courses on environment, sustainability and ethics. That helped in raising sustainability awareness among the student population. Nonetheless, research, community outreach and campus sustainability practices still need to be addressed.

Presenting a case study from the Reorient University Curricula to address sustainability, Kanbar (2012), assessed the need for education for sustainable development through an examination of students' attitudes and competence, in the Faculty of Business Administration and Economics (FBAE) at Notre Dame University (NDU) in Lebanon. The study's main finding uncovers a need to reorient university courses to address sustainability issues. 
Unruh-Snyder et al. (2011) discussed the impact of a study abroad course in Costa Ricain the area of agricultural sustainability and cultural awareness. Using an experimental design consisting of a pretest, a 7-week intervention and a post test, the authors noted that the course enhanced the cultural awareness of the participants.

Johnson (2009) explored notions of development and the role of the Association of African Universities (AAU) in promoting development. He also looked into how faculty and administrators at two African universities perceive development. The author found that from the perspective of policy entrepreneurship, the AAU, acted as an agent in development via activities aimed at addressing development priorities when using higher education as a point of intervention

Michael (2008) studied the suitability of HEI's in Pakistan to play a leading role toward education for sustainable development. He concluded by highlighting the reasons which make Pakistani HEI's suitable contenders for leadership in this regard, exclusively and without proper linkages to government, communities, NGOs and private sector.

\section{The Theory, the Model and the Framework}

\subsection{The Triple Bottom Line (TBL)}

Based on the notion of profit, people and planet (3P's), the Triple Bottom Line emerged in the 1990's, from work done by Elkington (1994), to measure sustainability in corporate America. It was the most basic model of describing and measuring sustainability efforts. For the first time, the model went beyond the traditional measures of profits, return on investment, and shareholder value to include environmental and social dimensions (Slaper and Hall, 2011). The notion behind the model is simple and straightforward. The one traditional bottom line of profits in organizations and entities is considered now in tandem with society and the environment.

As Johnson (Forum for the Future, 2006-07) states, "The Triple Bottom Line is conceptually easy to grasp, but very hard to deliver in reality, as it is still vague and offers no prescriptive solutions." Yet the simplicity of the model makes it flexible enough to adapt and modify. For instance, it can be expanded to include such aspects as justice, human rights, equality, culture etc.

\subsection{The Natural Step Model (NSM)}

Attempts to resolve the difficulty of prescriptive solutions, which characterizes TBL, resulted into the development of the Natural Step Model. The notion behind NSM is to limit or minimize human actions affecting nature (Robert, 1991), via a scientific approach of employing theory of systems thinking.

As Johnson (Forum for the Future, 2006-07) explains, four system thinking conditions combine to translate into four concrete principles of sustainability deemed characteristic of the desired sustainable society. In accordance with these principles, humans must eliminate their contributions to:

1. The buildup of substances extracted from the Earth's crust (i.e. fossil fuels, metals) 
2. The buildup of chemicals produced by humans (i.e. dioxins)

3. The degradation of nature and natural processes (i.e. deforestation)

4. Undermining people's capacity to meet their basic needs (i.e. unsafe working conditions)

Many organizations have adopted these principles in the ways they interact with nature, since the development of the model. Yet, although the model is more prescriptive than the TBL, it focuses attention a lot more on the environment at the expense of other elements of sustainability.

\subsection{The Five Capitals Model (FCM)}

Departing from a different and more pragmatic approach based on economics, the Five Capitals Model considers that any organization has stocks to manage in five capitals: natural, social, human, financial and manufactured (Porritt, 2005). Each capital can be defined and its stocks evaluated, in accordance with the table below:

Table 1: Five Capital Model of the Economy

\begin{tabular}{|l|l|l|}
\hline Capital & Stock & Flow \\
\hline Natural & $\begin{array}{l}\text { Land, sea, air, vegetation, } \\
\text { ecological systems }\end{array}$ & $\begin{array}{l}\text { Food, water, energy, waste, } \\
\text { disposal, climate }\end{array}$ \\
\hline Human & $\begin{array}{l}\text { Knowledge, skills, health, } \\
\text { motivation, spiritual ease }\end{array}$ & $\begin{array}{l}\text { Happiness, creativity, } \\
\text { innovation, work, energy, } \\
\text { participation }\end{array}$ \\
\hline Manufactured & $\begin{array}{l}\text { Families, communities, } \\
\text { organizations, governance } \\
\text { systems, schools }\end{array}$ & $\begin{array}{l}\text { Security, shared goods (e.g., } \\
\text { culture, education) inclusion, } \\
\text { justice }\end{array}$ \\
\hline Financial & $\begin{array}{l}\text { Infrastructure, roads, } \\
\text { buildings, tools, fixed assets }\end{array}$ & $\begin{array}{l}\text { Living/working space, access, } \\
\text { distribution }\end{array}$ \\
\hline $\begin{array}{l}\text { Money, stocks, bonds, } \\
\text { banknotes }\end{array}$ & $\begin{array}{l}\text { Means of valuing, owning or } \\
\text { exchanging other four capitals }\end{array}$ \\
\hline
\end{tabular}

Source: Forum for the Future

According to the logic of this model, organizations and societies achieve Sustainability by living from the flows of the stocks rather than eroding them.

\subsection{The Analytical Framework}

This paper adopts the 12 Features of a Sustainable Society (Appendix ......) as an analytical framework derived from and based on the Five Capitals Model, used by the Forum for the Future (2003), to describe and analyze the sustainable practices and initiatives of a higher education institution.

In order to identify, the strategies, policies, plans, initiatives and practices pursued by a higher education institution, a self-evaluation structured interview/questionnaire was developed and used along the lines of the 12 features of a sustainable society. This design was used by Johnson in a research project conducted for purposes of the Forum for the Future and the OECD. It serves well the main aim and purposes of this paper, due to a number of considerations, among which are the following: 


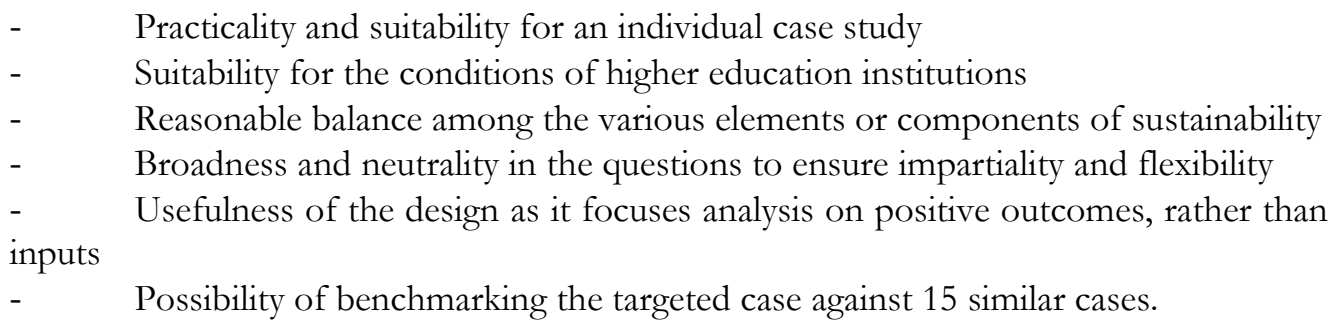

\section{Rafik Hariri University as a Case Study}

\subsection{University History and Overview}

The establishment of a higher education institution, accessible financially and geographically to all, was a pressing dream for His Excellency Prime Minister Rafik Hariri. In the early 1980s, PM Hariri chose Kfarfalous, an area between the South, Bekaa, and the mountains, to be the location for establishing a hospital and a university in collaboration with the University of Saint Joseph. However, the 1982 Israeli invasion led to the virtual destruction of the university and the theft of its equipment.

In 1984, the dream took a different turn with the establishment of the Rafik Hariri Foundation, a non-profit organization whose major goal was to provide the Lebanese youth with a chance for higher education in local and international universities. Around 33,000 Lebanese students benefited from the University Loan Program of the Rafik Hariri Foundation, and pursued their education in Lebanon, Europe, North Africa, and North America.

The end of the civil war in Lebanon led the Rafik Hariri Foundation to revive the dream of establishing an affordable, accessible university. The undertaking of such a project required the help of experts from a country that had made great strides in the field of education. Although several educationally advanced countries were considered, experts from Canada were eventually chosen for this collaboration. The programs of study at Rafik Hariri University were developed in association with a number of Canadian institutions, including the Canadian Bureau of International Education, the Canadian International Development Agency, Capilano University and Memorial University.

Rafik Hariri University, whose aim is to provide affordable, high quality education and to supply knowledgeable and competent graduates to meet Lebanese and regional job market demands, became a reality and opened its doors for the first time on September 15, 1999, with the College of Business Administration, according to Presidential Decree 1947. It opened with a student population of 75. After its Colleges of Engineering and Sciences and Information Systems were established, RHU was granted university status on June 19, 2006, by Decree Number 17192.

Today, Rafik Hariri University is a small and progressively growing private nonprofit institution of higher education, employing the American credit system of higher education, to offer over 20 graduate and undergraduate programs of study, in the College of Business Administration, College of Engineering, College of Computer Science and Information Systems, and the College of Arts. The University is currently undergoing 
two accreditation initiatives: one is with ABET for programs in the College of Engineering, and the other is with ACBSP for programs in the College of Business Administration.

\subsection{Major Initiatives}

Data and information collected from responses to the structured interview/questionnaire by the President, the Chair of the Sustainable Campus Initiative Committee, the Director of Facilities and Maintenance, the two authors of this paper, and a few faculty members, reveal that direct and explicit attention to sustainability as an issue and a priority at the institution is fairly recent (since 2015). In general, four major initiatives were observed.

\subsubsection{Environmental Sustainability: The Sustainable Campus Initiative.}

Efforts to provide the community at large with sustainability models started at the highest level of the university, with the formulation of the Sustainable Campus Initiative (SCI) and the establishment of the SCI Committee, in December of 2016. The aim of SCI is to transform RHU into a sustainable campus and culture, by undertaking and implementing university-wide transformative projects in all aspects of physical, environmental, educational and behavioral dimensions.

Meanwhile, an interdisciplinary committee was formed to direct, oversee and coordinate university sustainability projects and ensure appropriate and timely execution. The SCI Committee's first task was to reflect upon and formulate a long term systematic approach.

Since the launch of the SCI, and the formation of the SCI Committee, a number of projects have been initiated, and work is underway to accomplish the desired results. Below is a progress briefing of current projects.

\section{Solar Energy and the PV Plant}

The University installed a $100 \mathrm{~kW}$ rated solar PV plant, on the roof of three of RHU buildings, namely, Blocks F, G \& H, to substitute solar electricity for fossil fuel generated electricity.

The plant is a daytime plant - it does not need batteries to store energy for the night - it outputs during the day offsetting generator output. The plant output can now be followed live on RHU website. This in fact was the first PV plant to be installed and operated in a university in Lebanon. Moreover, since its inauguration, the plant has reduced the university's reliance on the national eletrical grid and on Diesel-oil Generators, thereby reducing usage of fossil fuel and emissions of harmful gases into the environment. Meanwhile, plant's data is being used by faculty and students to enhance research and learning. An additional $100 \mathrm{~kW}_{\mathrm{p}}$ plant is planned to be installed by the end of the 2017-2018 academic year.

\section{Rationalization of Water Usage}

In order to estimate the amount of ground water extracted and consumed at RHU, water flow meters were installed on the Campus main pipes. Weekly/monthly readings from these meters are recorded to determine usage needs and ensure minimization of waste. 
Moreover, the SCI includes plans to capture rain water from RHU premises to reduce ground water consumption.

\section{Installation of the Weather Station}

An up-to-date weather station was purchased and installed on RHU premises. Weather data is being collected and stored by the station and soon it will be feeding the data live on SCI website. Accumulation of data includes the amount of local rainfall, wind speed, humidity, temperature, pressure etc. The station is the first to be installed in the Middle East (except for one that is installed in the Golan Heights). RHU-Weather Station has become a part of global network of several hundred stations installed around the world (https://www.rhu.edu.lb/sustainable-campus-initiative).

\section{Reduce, Reuse, Recycle}

The SCI Committee has established a large composting pile, consisting of leftover carbon rich material collected from this year's pruning residues from the university trees and shrubs. A medium sized shredder was purchased and was used to shred all the pruning residues. Food remains, collected over several weeks, from the organic waste bins together with mowed grass clippings were used to initiate the composting process. The resulting final compost product was used as a fertilizer for trees and green grass on RHU premises. More 6,000 Liters of compost were produced, so far on RHU premises.

\section{Autonomous Solid Waste Treatment System}

This spring, work has already started to gradually develop an autonomous solid waste treatment system for all solid waste generated on campus. Sorting and recycling bins, already in place for many years now, have already been upgraded. Moreover, a sorting site has been selected, where volunteering faculty, students and staff gather to sort collected solid waste into plastics, glass, paper and organic residues. The SCI Committee takes measurements twice per week, in order to gauge usage and estimate quantities for purposes of developing a treatment model. The University's objective is to channel plastics, paper and glass to entities or firms which would reuse them as input. Meanwhile, a composting site would be put in place to transform organic residues into fertilizers, in collaboration with the community organization Arc en Ciel. Finally, an important objective for this initiative is to showcase it as a model of a sustainable community-driven solid waste management system solution.

\section{Green Buildings}

In order to transform the RHU campus into an environmentally friendly area, studies and plans are underway to turn as many university buildings as possible into green buildings. In fact, Block $\mathrm{E}$, which hosts most administrative functions and units, was selected to be the first green building on campus, and the current year should witness its completion. In addition, all buildings lights were changed to LED.

\section{Future Plans: Energy Conservation Prospects}

Prospects for energy conservation are currently being considered for potential implementation in the long term. For instance, the University boosts parking premises 
amounting to about 2,200m2. Such significant space dedicated solely for parking vehicles, may be used to build water reservoirs to collect rain water from RHU premises. The parking/reservoir space can be capped with a steel structure housing solar PV panels. This would have a triple advantage; it would serve as major rain water reservoirs; provide shading for the cars that get quite hot after several hours exposure to the sun and, would serve as a source of solar power.

Another possible long-term plan is the replacement of existing HVAC systems with central chillers. This can then be coupled with ground-source heat exchangers (geothermal energy). The latter source of energy alone has been shown elsewhere to reduce energy use by at least $32 \%$ for cooling and heating.

\subsubsection{General Sustainability: Curricular Courses}

The four colleges and associated departments have been studying the feasibility of offering specific sustainability programs, designed to supply the country (Lebanon) and the region (Arab World) with graduates who possess specialized competence and knowledge about sustainability issues. Although, such programs are still work in progress, one particular minor in sustainability program, in the College of Arts, is rapidly developing.

Aside from, and perhaps more important than specialized programs, the university has purposefully adopted an orientation of integrating a sustainability perspective into teaching and learning across many of its programs. Good progress seems to have been made, over the past three years. The table below lists courses involving various aspects of sustainability.

Table 2: Sustainability Perspective into Courses

\begin{tabular}{|c|c|c|}
\hline College & Course Title & Sustainability Aspects \\
\hline $\begin{array}{l}\text { College of } \text { Business } \\
\text { Administration }\end{array}$ & $\begin{array}{l}\text { Ethics and Social } \\
\text { Responsibility }\end{array}$ & $\begin{array}{l}\text { Contemporary principles of } \\
\text { ethics and social responsibility } \\
\text { in business. Including real } \\
\text { cases, critical analysis and } \\
\text { alternative solutions. }\end{array}$ \\
\hline $\begin{array}{ll}\text { College of } & \text { Business } \\
\text { Administration } & \end{array}$ & $\begin{array}{l}\text { Personal Development and } \\
\text { Management }\end{array}$ & $\begin{array}{l}\text { Self-awareness, ways, methods } \\
\text { and tools for personal growth } \\
\text { and management, based on } \\
\text { Arthur Chickering's Seven } \\
\text { Vectors Model. }\end{array}$ \\
\hline College of Arts & Social Psychology & $\begin{array}{l}\text { Use of specific social } \\
\text { psychological concepts to } \\
\text { "bridge the gap" between } \\
\text { understanding } \\
\text { implementing and } \\
\text { solutions to long-term } \\
\text { problems of sustainability. }\end{array}$ \\
\hline College of Arts & Psychology of Sustainability & $\begin{array}{l}\text { Psychological } \\
\text { principles, } \\
\text { theories, and methods to }\end{array}$ \\
\hline
\end{tabular}




\begin{tabular}{|c|c|c|}
\hline & & $\begin{array}{l}\text { examine the reciprocal } \\
\text { relationship between human } \\
\text { beings and the natural world, } \\
\text { including a review of } \\
\text { important psychological and } \\
\text { social factors that underlie a } \\
\text { range of sustainable and non- } \\
\text { sustainable behaviors }\end{array}$ \\
\hline $\begin{array}{l}\text { College of Sciences and } \\
\text { Information Systems }\end{array}$ & $\begin{array}{ll}\text { Introduction } & \text { to } \\
\text { Environmental Science }\end{array}$ & $\begin{array}{l}\text { Study of how humanity } \\
\text { interacts with nature, } \\
\text { emphasizing factors that may } \\
\text { contribute to environmental } \\
\text { sustainability such as } \\
\text { Stabilization of Populations, } \\
\text { Protection of Natural } \\
\text { Ecosystems etc. }\end{array}$ \\
\hline $\begin{array}{l}\text { College of Sciences and } \\
\text { Information Systems }\end{array}$ & Design II & $\begin{array}{l}\text { Sustainable packaging, its } \\
\text { benefits and the different } \\
\text { types of material that can be } \\
\text { used to reduce waste; } \\
\text { packaging projects that can be } \\
\text { reused or designed with the } \\
\text { concept of reducing food } \\
\text { waste }\end{array}$ \\
\hline College of Engineering & $\begin{array}{l}\text { Engineering for the } \\
\text { Community }\end{array}$ & $\begin{array}{l}\text { Research and prepare a term } \\
\text { paper around the theme of } \\
\text { sustainability in such areas as } \\
\text { waste management, energy } \\
\text { saving architecture, } \\
\text { active/passive renewable } \\
\text { energy sources, etc... }\end{array}$ \\
\hline College of Engineering & Environmental Engineering & $\begin{array}{l}\text { Sustainable engineering } \\
\text { practices for treating water and } \\
\text { wastewater, solid waste } \\
\text { management and air pollution. }\end{array}$ \\
\hline College of Engineering & Hydraulics & $\begin{array}{l}\text { Course includes an } \\
\text { introduction to sustainability } \\
\text { in storm water management }\end{array}$ \\
\hline College of Engineering & Hydrology & $\begin{array}{l}\text { Course covers aspects and } \\
\text { issues relating to sustainable } \\
\text { water management }\end{array}$ \\
\hline College of Engineering & $\begin{array}{l}\text { Water and Wastewater } \\
\text { Treatment }\end{array}$ & $\begin{array}{l}\text { Issues related to sustainable } \\
\text { utilization of water resources, } \\
\text { including analysis and } \\
\text { sustainable design of } \\
\text { conventional water treatment } \\
\text { systems and disposal }\end{array}$ \\
\hline College of Engineering & Solid Waste Management & Course covers basic principles \\
\hline
\end{tabular}




\begin{tabular}{|l|l|l|}
\hline & & $\begin{array}{l}\text { and recent advances for } \\
\text { handling solid waste in an } \\
\text { environmentally sustainable } \\
\text { way }\end{array}$ \\
\hline College of Engineering & $\begin{array}{l}\text { Environmental Impact } \\
\text { Assessment }\end{array}$ & $\begin{array}{l}\text { Course provides an overview } \\
\text { of the principles, processes } \\
\text { and practices for assessing } \\
\text { environmental impact from a } \\
\text { sustainability perspective }\end{array}$ \\
\hline
\end{tabular}

As the table above shows, the university has already integrated a sustainability perspective, as appropriate, in all of its colleges (4 colleges). While environmental sustainability is heavily emphasized in many courses in the college of engineering, social sustainability is addressed in a couple of courses in the college of arts, and social/economic sustainability is also addressed in a couple of courses in the college of business administration.

\subsubsection{Social Sustainability: The Community Engagement Experience}

In the academic year 2016-2017, the College of Business Administration at RHU integrated into its curriculum and programs a requirement entitled Community Engagement Experience. With this initiative in place, RHU became one of a very few universities in the country undertaking similar efforts. Under the auspices of this initiative, business students are required to complete no less than 40 hours of targeted and project based voluntary community service, at various nonprofit and/or none governmental organizations. At the end of the experience, students are systematically evaluated by assigned faculty advisors and by their supervisors from the organizations.

The main objective of this course is to open up an opportunity for students to develop leadership and initiative skills, via engagement in socially responsible actions undertaken by community organizations, for the purpose of community and social development. Meanwhile, the course's three main outcomes are as follows:

1) Participate in a first-hand experience in socially responsible actions

2) Develop introductory and basic awareness of community service and community development

3) Demonstrate teamwork skills via engagement in collective efforts/projects/initiatives carried out for non-profit purposes.

In the course's first year of implementation, 68 students completed their Community Engagement Experience at 32 different community organizations, spread geographically all over the country. A sample of participating organizations included Friends of the Disabled Association, Beirutiyat, Ahlouna, Amal Ataaa Association and the Lebanese Red Cross. Moreover, 48 students are completing their experience this summer in more than 20 different organizations.

\subsubsection{Economic Sustainability: The Incuvation Initiative}

As a life changing medium, RHU launched in academic year 2016-2017 an Incuvation (Incubation Innovation) platform to help potential innovators refine 
promising ideas and transform them into living organisms that could make a difference. This initiative was inspired by a desire to help students create sustainable work opportunities, by combining entrepreneurial tendencies with innovative mind sets, in a country where the unemployment rate among youths hovers around $35 \%$.

Any student or a group of students enrolled at RHU may submit a My Idea to Innovate proposal application to receive an Incuvation award. Proposals are appraised by a committee of faculty members and external advisors on the basis of originality, merit, potential of success, and scale against the Incuvation Award Rubric. The winners will have the following support tools as they pursue a degree at RHU:

1. Unlimited access to lab equipment and support of lab engineers

2. Faculty mentors to guide them and help them resolve technical issues

3. Funds for equipment, software or other tools that may not be available at RHU

4. Work study and graduate assistant support

5. Curricular flexibility to design courses with the help of faculty mentors that enable coverage of topics that are not offered in the mainstream curriculum

6. Training to develop specific skills not attained in the regular program offering.

\subsubsection{Other Sustainability Actions}

While the four major initiatives discussed above encompass to a large extent what the university has been doing with regard to sustainability, data and information collected via the interview/questionnaire revealed additional aspects and actions. Below is a summary of what we were able to identify.

- $\quad$ Replacement of all light bulbs into LED bulbs to save on use of electricity and energy

- Installation of central switches for lights and peripherals in classrooms that can only be activated by faculty members

- Smoking is allowed in only four designated outdoor locations on campus

- A counselling services center staffed by a professional counselor was established to provide needed help and assistance to students

- On campus medical clinic with a full-time registered nurse is available for students

- $\quad$ Four student learning support centers provided peer-peer learning for students with performance difficulties

- Over a dozen professional student clubs and about 20 interest student clubs function with financial support from the university

- $\quad$ Students enjoy the services of an athletic department which operates a number of facilities, as such training center, courts etc., to support several sports teams.

- Development of a botanical garden on campus 


\subsection{Analysis and Interpretations}

Analysis and interpretations of the data and information, collected from the interview/questionnaire used, reveal a number of observations and remarks.

First, attention to sustainability and the importance of the university in the quest for a sustainable society picked up during the past three years. This coincided with a change of leadership, which brought to the university a president who has placed sustainability up high on the agenda. Aside from the actions and initiatives undertaken by the university, there seems to be a widespread awareness, among administrators, faculty and staff, which is gradually trickling down toward students, that sustainable development is an important priority in the normal flow of work in a university.

Second, the university is clearly interested not only in integrating sustainability into teaching and learning, but also in deliberate actions targeting showcasing the university as a small micro-model for how to solve sustainability problems and issues. Success in this regard shall prove to be beneficial for Lebanese society, as it faces a number of serious challenges, particularly in things like waste management, pollution, electricity shortages, corruption and similar problems.

Third, On the basis of the fifteen case studies reported by the Forum for the Future (2006-207), Rafik Hariri University appears to show similar results in that sustainability continues to be defined in relatively narrows terms for HEIs, with a strong focus on environmental sustainability and a weaker focus on social and economic sustainability. Yet, the Incuvation initiative and the community Engagement Experience initiative at RHU do provide a good basis to rebalance the university's approach toward comprehensive sustainability.

Fourth, Rafik Hariri University does also show similar results in the area of teaching and learning. Several aspects of sustainability are being taught and covered in at least a couple of curricular courses in each of the four colleges. However, specialized sustainability programs are yet to make their way into the university's offering of programs. The university's slowness in this regard may be justified by its small size, which may be dictating a more thorough and careful consideration prior to launching new programs of study.

Fifth, unlike the fifteen case studies reported by the Forum for the Future, RHU does not seem to be active in researching issues around sustainability, mainly focusing on environmental and ecological concerns. For the fifteen case studies, active research is driven by climate change and energy concerns, which receive significant funding from government and industry. For RHU, the university's orientation as a primarily teaching institution, combine with the inadequacy of government and industry funding, to hinder research and studies.

\subsubsection{Sustainability: Environmental, Social and Economic.}

In the area of environmental sustainability, the Sustainable Campus Initiative puts RHU in par with other HEI's, as reported by the Forum for the Future. Focus of the actions undertaken under the initiative revolves around the issues of greening the campus, using alternative and more sustainable sources of energy and reducing waste and usage of natural resources. Moreover, the actions undertaken seem to be gradually evolving into a sustainable environmental management system for the university. With 
regard to the scope of environmental sustainability actions, RHU is closer to HEIs which have whole campus plans including all environmental issues, compared to others who include only a part of the HEI or only some key environmental issues such as water and energy.

Similar to other HEI's, RHU is much more on the side of natural resources usage, as opposed to extraction, and the latter is being targeted for improvement via actions like rationalization of water usage and substitution of solar energy for fossil fuel sources. Finally, with regard to biological diversity, the RHU campus is in full harmony with its surroundings, where buildings are mostly built with local natural stones in compliance with local and national construction zoning specifications. Moreover, a variety of tree and flower species is maintained throughout campus.

In the area of social sustainability, RHU like most HEI's is expanding the availability of professional and personal development programs and courses for faculty, staff and students. Moreover, the university made significant improvements in the area of occupational health practices and facilities for staff and students.

In particular, the Community Engagement Experience in the College of Business Administration systematically requires students to seek volunteer opportunities and work on community projects, in order to enhance their skills and develop a sense of community. Strengthening links with the community and industry is also targeted by faculty members in the four colleges, via encouraging students to seek and work on real problems and issues from the community in their graduation projects.

In the area of economic sustainability, the university is banking on being able to promote innovation and entrepreneurship. The launch of the Incuvation initiative this academic year was a major step in this direction. This academic year marked also another step in this direction, which involved adoption, including allocation of resources, of three keystone projects, aiming to innovatively use the latest in technological breakthroughs, in order propose solutions for major national problems, and/or produce new products and services.

\subsection{Conclusions and Recommendations}

The Sustainable Development Goals (SDG's) formulated and adopted by the United Nations mark an important and ambitious step on the global agenda of our world. As proliferated and far reaching as they are, they provide due focus, guidance and orientation for our efforts toward a sustainable way of life on our fragile planet.

The role of HEI's in the march toward attainment of SDG's may had been confused at one juncture, and possibly out of sync at another. Yet, it has become clearer and more self-evident, in light of important developments in the higher education agenda, as it pertains to sustainability. Nonetheless, efforts, research and studies should enrich our knowledge by shifting the balance away from the why question and toward the how question.

While higher education for sustainability is vital to the development of developing world societies, HEI's in the developing world may still be more concerned with solving more basic and essential needs problems. Efforts and initiatives exist but they are either too few or too poorly researched and reported. 
Rafik Hariri University, as the case study of this paper, has made good progress toward the integration of sustainability into its educational experience, during a short period of time, given its troubled and unstable national environment, small size and resources limitations. With its Sustainable Campus Initiative, the Community Engagement Experience, and Incuvation Initiative, among other efforts, the university is set to gradually make an impact within the next few years, and position itself as a national and regional leader on sustainability. To that extent, and based on our research and analysis in this paper, RHU could benefit from:

1) Developing and adopting a sustainability strategic plan and integrating it within its strategic planning. This step would better focus the university's initiatives and target efforts and resource allocation.

2) Expanding the scope of its sustainable campus initiative to include aspects of social and economic sustainability.

3) Seeking partnerships for sustainability with pertinent government, industry and civil society organizations.

4) Considering leading an initiative to establish a national higher education for sustainability network modeled along the lines of such existing networks as MESA in Africa, ProsPER.Net in Asia-Pacific, COPERNICUS Alliance in Europe, and ARIUSA in Latin America and the Caribbean.

\section{Appendix A: Features of a Sustainable Society}

\section{Of natural capital}

1. In their extraction and use, substances taken from the earth do not exceed the environment's capacity to disperse, absorb, recycle or otherwise neutralize their harmful effects (to humans and/or the environment)

2. In their manufacture and use, artificial substances do not exceed the environment's capacity to disperse, absorb, recycle or otherwise neutralize their harmful effects (to humans and/or the environment)

3. The capacity of the environment to provide ecological system integrity, biological diversity and productivity is protected or enhanced.

\section{Of human capital}

4. At all ages, individuals enjoy a high standard of health.

5. Individuals are adept at relationships and social participation, and throughout life set and achieve high personal standards of their development and learning.

6. There is access to varied and satisfying opportunities for work, personal creativity and recreation.

\section{Of social capital}

7. There are trusted and accessible systems of governance and justice.

8. Communities and societies at large share key positive values and a sense of purpose.

9. The structures and institutions of society promote stewardship of natural resources and development of people. 
10. Homes, communities and society at large provide safe, supportive living and working environments.

\section{Of manufactured capital}

11. All infrastructure, technologies and processes make minimum use of natural resources and maximum use of human innovation and skills.

\section{Of financial capital}

12. Financial capital accurately represents the value of natural, human, social and manufactured capital.

\section{Appendix B: Interview/Questionnaire for Higher Education Institutions (HEI's)}

Question 1: How does your HEI contribute to reducing the extraction of natural resources?

Question 2: How does your HEI contribute to reducing the use of natural resources?

Question 3: How does your HEI contribute to improving biological diversity?

Question 4: How does your HEI contribute to improving the health and well-being of staff and students?

Question 5: How does your HEI contribute to building the learning and social skills of staff and students so that they are empowered citizens?

Question 6: How does your HEI provide access to varied and satisfying opportunities for personal creativity, well-being and recreation for all stakeholders?

Question 7: How does your HEI improve governance systems so that they are trusted by all stakeholders and accessible to them?

Question 8: How are your HEI's s policies, teaching practices, research and third stream activities contributing to a shared understanding of sustainable development amongst internal and external stakeholders?

Question 9: How does your HEI support other businesses, the public sector and voluntary groups in society to promote stewardship of natural, social and economic resources?

Question 10: How does your HEI contribute to safe and supportive local communities?

Question 11: How does your HEI contribute to the development of infrastructure, technologies and processes that minimize use of natural resources and maximize use of human innovation and skills?

Question 12: How does your HEI ensure economic sustainability including the financial valuation of natural (e.g. the extra cost of green energy) and social capital?

Question 13: Could you please state the barriers and opportunities to implementing sustainable development at your institution and any policy suggestions you have.

\section{References}

Association of University Leaders for a Sustainable Future (1990). The Talloires Declaration: 10 point action plan. http://ulsf.org/wp-content/uploads/2015/06/TD.pdf. Retrieved on May 2, 2018. 
Awuzie, B., Emuze, F. (2017). Promoting sustainable development implementation in higher education: Universities in South Africa. International Journal of Sustainability in Higher Education, 18(7), 11761190. https://search.proquest.com/docview/1960520186? accountid $=158790$

Retrieved on June 4, 2018

Barth, M., Rieckmann, M. (2016). State of the art in research on higher education for sustainable development. In Barth, M., Michelsen, G., Rieckmann, M., Thomas, I. (Eds.), Routledge bandbook of bigher education for sustainable development (pp. 100-113). London, England: Routledge. Google Scholar

Bhat, S. A., Zahid, A. T., Sheikh, B. A., \& Parrey, S. H. (2017). Environmental education in India: An approach to sustainable development. FIIB Business Review, 6(1), 14-21. https://search.proquest.com/docview/1966794885?accountid=158790 Retrieved on June 4, 2018

Clugston, R., Calder, W. (1999). Critical dimension of sustainability in higher education. In Leal Filho, W. (Ed.), Sustainability and university life (pp. 31-46). Frankfurt, Germany: Peter Lang. Google Scholar

COPERNICUS (2001). The Luneburg Declaration on higher education for sustainable development.

https://www.iau-hesd.net/sites/default/files/documents/2001 - the luneburg declaration fr.pdf Retrieved on June 20, 2018.

COPERNICUS (1994). The university charter for sustainable development.

https://www.iau-hesd.net/sites/default/files/documents/copernicus.pdf Retrieved on June 19, 2018.

Corcoran, P., Walker, K., Wals, A. (2004). Case studies, make-your-case studies, and case stories: A critique of case-study methodology in sustainability in higher education. Environmental Education Research, 10, 7-21. Google Scholar, Crossref

Cusick, J. (2008). Operationalizing sustainability education at the University of Hawaii at Manoa. International Journal of Sustainability in Higher Education, 9, 246-256. Google Scholar, Crossref

Desha, C., Hargroves, K., Smith, M. (2009). Addressing the time lag dilemma in curriculum renewal towards engineering education for sustainable development. International Journal of Sustainability in Higher Education, 10, 184-199. Google Scholar, Crossref

Doniec, A. (2006). Sustainability questions in the curriculum of Faculty of Organization and Management at the Technical University of Lodz. Clean Technologies and Environmental Policy, 8, 20-23. Google $\underline{\text { Scholar, }} \underline{\text { Crossref }}$

Elkington, J. (1994). Towards the sustainable corporation: Win-win-win business strategies for sustainable development. California Management Review 36, no. 2 (1994): pp 90-100.

Fien, J. (2002). Advancing sustainability in higher education: Issues and opportunities for research. Oxford, UK: International Association of universities. Google Scholar

Fonseca, A., Macdonald, A., Dandy, E., Valenti, P. (2011). The state of sustainability reporting at Canadian universities. International Journal of Sustainability in Higher Education, 12, 22-40. Google Scholar, Crossref, ISI

Forum for the Future (2006-2007). Higher education for sustainable development: Final report of International Action Research Project. Forum for the Future, London.

Forum for the Future (2003). Reporting for sustainability: Guidance for bigher education institutions, Forum for the Future, London.

International Association of Universities (1993). Kyoto Declaration on sustainable development. https://www.iauaiu.net/IMG/pdf/sustainable development policy statement.pdf Retrieved on June 18, 2018.

Johnson, A. T. (2009). Mobilizing higher education for development in africa: A case study of the association of African universities (Order No. DP19041). Available from ProQuest Central. (1020575670). https://search.proquest.com/docview/1020575670?accountid=158790

Retrieved on May 30, 2018

Kagawa, F. (2007). Dissonance in students' perceptions of sustainable development and sustainability: Implications for curriculum change. International Journal of Sustainability in Higher Education, 8, 317338. Google Scholar, Crossref

Kanbar, N. (2012). Can education for sustainable development address challenges in the Arab region? Examining business students' attitudes and competence on education for sustainable development: A case study. Discourse and Communication for Sustainable Education. Vol. 3, pp. 41-62, DOI: $10.2478 /$ v10230-012-0003-0 
Karatzoglou, B. (2012). An in-depth literature review of the evolving roles and contributions of universities to education for sustainable development. Journal of Cleaner Production, 49, 44-53. Google Scholar,

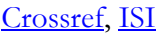

Kieu, T. H., Singer, J., Gannon, T. J. (2016). "Education for sustainable development in Vietnam: Lessons learned from teacher education", International Journal of Sustainability in Higher Education, Vol. 17 Issue: 6, pp.853-874, https://doi.org/10.1108/IJSHE-05-2015-0098

Khalaf-Kairouz, L. (2012). Education for sustainable development at Notre Dame University- Louaize: Environmental Science Curriculum - A Pre-phase to the Rucas Project on Education for Sustainable Development. Discourse and Communication for Sustainable Education. Vol. 3, pp. 121-134, DOI: $10.2478 / \mathrm{v} 10230-012-0009-7$.

Leal Filho, W. (2011). About the role of universities and their contribution to sustainable development. Higher Education Policy, 2011, 24, (427 - 438)

Leal Filho, W. (2000). Dealing with misconceptions on the concept of sustainability. International Journal of Sustainability in Higher Education 1(1): 9-19.

Lozano, R., Lukman, R., Lozano, F., Huisingh, D., Lambrechts, W. (2011). Declarations for sustainability in higher education: Becoming better leaders, through addressing the university system. Journal of Cleaner Production, 48, 10-19. Google Scholar, Crossref, ISI

Magna Charta Universitatum (1988). http://www.magna-charta.org/resources/files/the-magnacharta/english. Retrieved on May 2, 2018.

McMillin, J., Dyball, R. (2009). Developing a whole-of-university approach to educating for sustainability: Linking curriculum, research and sustainable campus operations. Journal of Education for Sustainable Development, 3, 55-64. Google Scholar, SAGE Journals

Meakin, S. (1992). The Rio Earth Summit: Summary of the United Nations Conference on Environment and Development. http://publications.gc.ca/Collection-R/LoPBdP/BP/bp317-e.htm Retrieved on June 6, 2018

Michael, S. (2008). The Role of Universities in Sustainable Development with Special Focus on Pakistan.

http://dspace.unimap.edu.my/xmlui/bitstream/handle/123456789/5828/THE\%20ROLE\%20OF\%20UNI VERSITIES\%20IN\%20SUSTAINABLE\%20DEVELOPMENT\%20WITH\%20SPECIAL\%20F OCUS $\% 20$ ON $\% 20$ PAKISTAN.pdf? sequence=1 Retrieved on June 19, 2018.

Mohamedbhai, G. (2012). Promoting sustainable development in Africa through higher education. Conference paper. http://www.tec.mu/pdf downloads/confpaper/conference2012/confpaper1.pdf Retrieved on April 30, 2018

Owens, T. L. (2017). Higher education in the sustainable development goals framework. European Journal of Education. 2017; 52:414-420. DOI: 10.1111/ejed.12237

Pisano, U., Andreas, A., and Berger, G. (2012). The Rio+20 conference 2012: Objectives, processes and outcomes. ESDN Quarterly Report $\mathrm{N}^{\circ} 25 . \quad$ http://www.sdnetwork.eu/quarterly $\% 20$ reports/report $\% 20$ files/pdf/2012-JuneThe Rio+20 Conference 2012.pdf Retrieved on June 6, 2018.

Porritt, J. (2005). Capitalism as if the world matters. London, Earthscan Publications Ltd.

Robért, K.H. (1991). "Educating a Nation: The Natural Step", In Context, No. 28, Context Institute, pp. 10.

Shephard, K. (2016). Individual change: Researching educational outcomes achieved by higher education for sustainable development. In Barth, M., Michelsen, G., Thomas, I., Rieckmann, M. (Eds.), Routledge handbook of higher education for sustainable development (pp. 261-272). London, England: Routledge. Google Scholar

Shriberg, M. (2004). Assessing sustainability: Criteria, tools, and implications. In Corcoran, P. B., Wals, A. E. J. (Eds.), Higher education and the challenge of sustainability (pp. 71-86). New York, NY: Kluwer Academic. Google Scholar, Crossref

Simon, K. and Haertle, J. (2014). Rio+20 Higher Education Sustainability Initiative (HESI) Commitments A Review of Progress, October 2014. http://www.eauc.org.uk/theplatform/higher education sustainable initiative Retrieved One June 19, 2018.

Slaper, T. F., Hall T. J. (2011). The Triple Bottom Line: What is it and how does it work? Indiana Business Review. http://www.ibrc.indiana.edu/ibr/2011/spring/article2.html Retrieved on June 22, 2018 
Tapia-Fonllem, C., Frajio-Sing, B., Valdez, A. O. (2017). Education for sustainable development in higher education institutions: Its influence on the pro-sustainability orientation of Mexican students. SAGE Open, January-March 2017: 1-15. DOI: 10.1177/2158244016676295

UNESCO (2018). Issues and trends in education for sustainable development. http://unesdoc.unesco.org/images/0026/002614/261445e.pdf Retrieved on June 12, 2018

UNESCO (2017). Global action programme on sustainable development. bttp:// unesdoc.unesco.org/images/0024/002462/246270e.pdf Retrieved on June 12, 2018

UNESCO (2015). World conference on education for sustainable development conference report by the General Rapporteur Heila Lotz-Sisitka, Professor, Rhodes University http://unesdoc.unesco.org/images/0023/002328/232888E.pdf Retrieved on June 12, 2018.

UNESCO (2014). Shaping the future we want: UN decade of education for sustainable development (2005-2014) final report.

https://sustainabledevelopment.un.org/content/documents/1682Shaping $\% 20$ the $\% 20$ future $\% 20$ we $\% 20$ want.pdf Retrieved on June 13, 2018

United Nations (2015). Transforming our world: The 2030 agenda for sustainable development. bttps:// sustainabledevelopment.un.org/content/documents/21252030\%20 Agenda\%20for\%20Sustainable\%20 Development\%20web.pdf Retrieved on April 27, 2018

United Nations (2012). Higher education sustainability initiative. https://sustainabledevelopment.un.org/index.php?menu=1073 Retrieved on June 19, 2018.

United Nations (2002a). Report of the world summit on sustainable development. http://www.undocuments.net/aconf199-20.pdf Retrieved on June 13, 2018.

United Nations (2002b). Johannesburg declaration on sustainable development. http://www.undocuments.net/iohannesburg-declaration.pdf Retrieved on June 13, 2018

United Nations (1992a). The Rio declaration on environment and development. http://www.unesco.org/education/pdf/RIO E.PDF Retrieved on June 7, 2018

United Nations (1992b). Agenda 21. https://sustainabledevelopment.un.org/content/documents/Agenda21.pdf Retrieved on June 13, 2018

United Nations (1992c). Non-legally binding authoritative statement of principles for a global consensus on the management, conservation and sustainable development of all types of forests. https://www.un.org/documents/ga/conf151/aconf15126-3annex3.htm Retrieved on June 14, 2018

United Nations (1987). Our common future: Report of the World Commission on Environment and Development. bttp:// wnw.exteriores.gob.es/Portal/ es/PoliticaExteriorCooperacion/Desarrollosostenible/Documents/Informe\% 20Brundtland\%20(En\%20ingl\%C3\%A9s).pdf Retrieved on April 27, 2018

United Nations (1972a). Report of the United Nations conference on the buman environment. http://www.undocuments.net/aconf48-14r1.pdf Retrieved on June 14, 2018

United Nations (1972b). Declaration of the United Nations conference on the Human Environment. http://www.undocuments.net/unchedec.htm Retrieved on June 14, 2018

United Nations Environmental Program (2012). The Global universities partnership on environment for ustainability http://gupes.org/index.php?classid=3235 Retrieved on June 20, 2018.

Unruh-Snyder, L., Lamm, A. J., Brendemuhl, J., Irani, T., Roberts, T. G., Rodriguez, M. T., \& Navarro, J. (2011). Enhancing cultural awareness through an agricultural sustainability course in Costa Rica. Journal of Natural Resources and Life Sciences Education, 40(1), 191-198. doi:http://dx.doi.org/10.4195/jnrlse.2010.0033u

Wals, A. (2009). A mid-DESD review: Key findings and ways forward. Journal of Education for Sustainable Development, 3, 195-204. Google Scholar, SAGE Journals

Wright, T., Pullen, S. (2007). Examining the literature: A bibliometric study of ESD journal articles in the Education Resources Information Center Database. Journal of Education for Sustainable Development, 1, 77-90. Google Scholar, $\underline{\text { SAGE Journals }}$ 